ISSN 0975-3311

UJBM, Vol. 8, No. 2, July - December 2009, pp 67-66

ISSN 0975-3311 | https://doi.org/10.12725/ujbm.15.7

\title{
TALCUM POWDER: PROBLEMS AND SATISFACTION OF CONSUMERS
}

\section{Muthamizh Vendan Murugavel*}

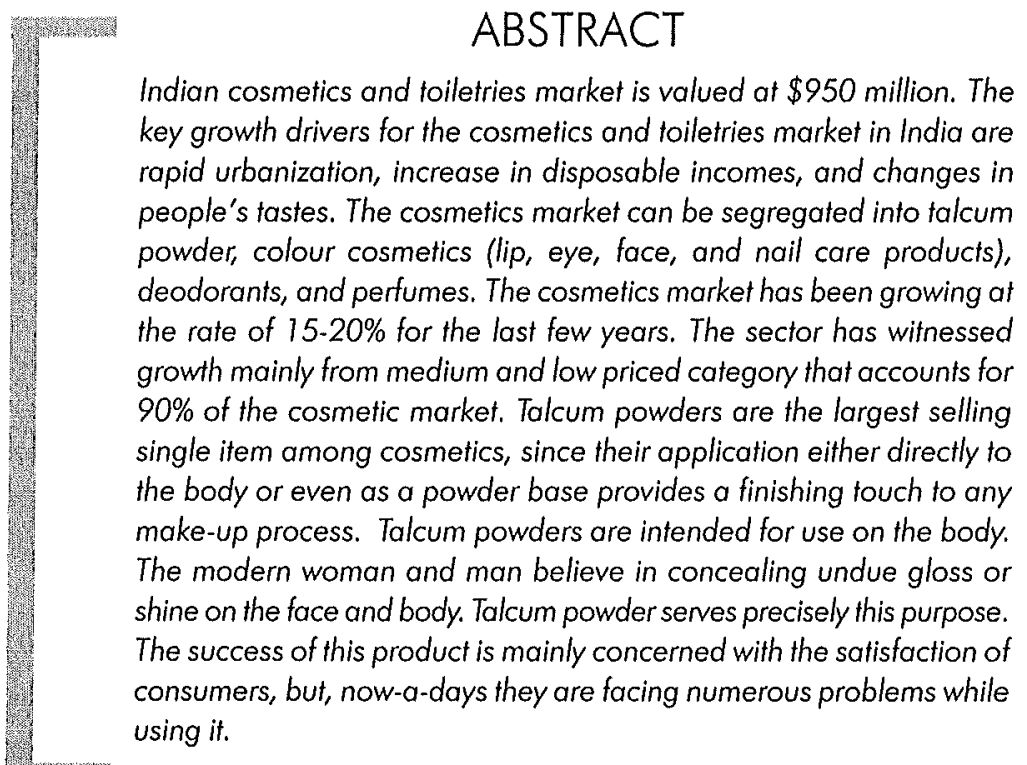

* P.G. Dept. of Commerce, Gobi Arts \& Science College, Gobi, Tamil Nadu. 


\section{Introduction}

Consumers play a very important role in the economy. They are the largest economic group in any country. All our present day activities are because of consumer only. Consumers are the pillars of the economy. They are free to buy goods of the kind they like and the producer have to ascertain the tastes and preferences of this group and produce only those goods which will help them to satisfy their needs and desires. But in the modern marketing system, consumer sovereignty is a myth on account of variety of problems in the process of production and distribution. While using any product the consumers are encountering numerous problems which in turn may affect their level of satisfaction.

Talcum powder is one of the popular cosmetics used by the consumer. Cosmetics are those articles which are intended to be rubbed, poured, sprinkled or sprayed or othenwise applied to the human body or any part thereof for beautifying or altering the appearance. Cosmetics may clean the skin or change its colour but they do not prevent or cure any dermal condition. It has been traditionally used for its fragrance and feeling of freshness. Talcum powders are the largest selling single item among cosmetics, since their application either directly to the body or even as a powder base provides a finishing touch to any make-up process. Talcum powders are intended for use on the body. Both men and women have been using cosmetics for thousands of years. These products help in beautifying, promoting, attractiveness of men and women.

\section{Talcum Powder Market in India}

Talcum powder market is a growing segment of the personal care products industry. Thinking small can have big advantage, especially when market forces and technology are the ground rules for industrial competition. In this industry, there is a high entry barrier due to the strong brand presence of the existing players. Companies are channelising greater part of their resources towards promotion of new products.

Talcum powder is one of the most popular cosmetic products in India. Its market is valued at Rs.3.5 billions and is growing at the rate of $12 \%$ per annum. Its penetration level is $45.4 \%$ and $25.2 \%$ in urban and rural areas respectively. Ponds dominate talcum powder market with a market share of $70 \%$ followed by Johnson \& Johnson with a market share of $15 \%$. 
Gone are the days when cosmetics were viewed as expensive and selfindulgent items. Greater accesses to television, increased advertisement and greater product choice and availability have resulted in growing demand for cosmetic products in India. However, the penetration level of cosmetics and toiletries product is still very low in India. The per capita expenditure on cosmetic products in India is approximately $\$ 0.68$ cents compared to $\$ 36.65$ in other Asian countries. The penetration level of international cosmetics brand in India is also low. International brands account for only $20 \%$ of the cosmetics market. This low level of market penetration can be perceived as an opportunity for major player in FMCG sector.

\section{Literature Review}

Dr. K. Chidabaram and Dr. S. Ganesan conducted a study on, "Brand preference of Talcum powder". They suggested that manufacturers are taking only a little effort to solve the problems of consumers and simply the manufacturers have been interested to increase the sales.

Bhawna Garg conducted a study on "Rural Marketing - study of Consumer Behaviour with reference to Hair oils". He suggested that Television advertising had a deep impact on the minds of consumers from the village.

Vidyadhar Reddy Ailen conducted study on "Advertising effectiveness of Toilet soaps" in the cities of Hyderabad and Secunderabad. He suggested that the frequency rate of advertisements should be increased in order to attract more consumers towards exposure of those advertisements.

A.V. Ramana and P. Viswanath conducted a study on "Consumer Behaviour and Awareness with special reference to Edible oil users". They found that head of the family and advice of family members are the most influencing factors in choosing a brand. 'However, doctors' advice has also become one of the influencing factors followed by the advice of neighbours and relatives.

\section{Objectives of the Study}

1. To analyse the problems faced by consumers of talcum powders.

2. To ascertain the level of satisfaction of consumers about their brand. 


\section{Methodology and Sample Design}

The study is purely based upon primary data. The primary data were collected through personal interview with the help of a structured interview schedule. The present study is related to consumers of most familiar Talcum powder products such as Ponds, Cinthol, Spinz, Gokul Sandal, and Mysore Sandal. To study the problems and satisfaction level of consumers of talcum powder, 100 sample respondents were selected in the Avinashi town by adopting convenience sampling method. The sample consists of people such as businessmen, professionals, employees, homemakers and students.

\section{Statistical Tools Used}

The primary data collected from 100 sample respondents are analysed with the help of statistical tools such as Weighted Ranking analysis, Likert scaling technique and Chi-square test.

\section{Weighted Ranking Analysis}

As per this method, weighted score $(\mathrm{fx})$ is calculated by multiplying the assigned score value $(X)$ and number of respondents $(f)$ is totalled and the rank is assigned on the basis of the total score. The factor scoring the highest value is considered as the most important factor. Rank is assigned on the basis of descending order to the total score.

\section{Problems Faced by the Consumers of Talcum Powders}

Due to skin consciousness among the people many talcum powder with different brands have entered into the market from time to time. It has been reported that the manufacturers are resetting too many malpractices in different ways such as selling low quality product, low weight, adulteration, charging high prices by creating artificial scarcity and also with misleading advertisements. The talcum powder consumers are mainly facing the problems such as low quality, higher price, health problems, non-availability, chemical mixing, poor packing, \& low quantity etc. while using a particular brand. 
Table 1 : Problems Faced by the Consumers of Talcum Powders

\begin{tabular}{|l|c|c|c|}
\hline Problems & Total score & Mean score & Rank \\
\hline Not an Affordable Cost & 430 & 43.0 & II \\
Non-Availability of Preferable Size & 356 & 35.6 & $\mathrm{~V}$ \\
Misleading Advertisements & 366 & 36.6 & $\mathrm{IV}$ \\
Adulteration \&Malpractices & 352 & 35.2 & $\mathrm{VI}$ \\
Choice of Brands & 415 & 41.5 & III \\
Poor \& Less Attractive Package & 342 & 34.2 & VII \\
Chemical Mixing \& Skin Allergy & 450 & 45.0 & I \\
Irregular Supply & 332 & 33.2 & VIII \\
\hline
\end{tabular}

Source: Primary data

\section{Satisfaction Level of Talcum Powder Consumers}

To measure the satisfaction level, factors such as quantity, price, quality, fragrance, advertisements, availability of different size packs, regular supply, freshness \& beauty maintenance, brand image and package were considered. A Five point Likert's scale was used.

Table 2 : Classification of Sample Respondents according to their Level of Satisfaction

\begin{tabular}{|l|c|c|}
\hline Satisfaction Level & No. of Respondents & Percentage \\
\hline High & 76 & 76 \\
Low & 24 & 24 \\
Total & 100 & 100 \\
\hline
\end{tabular}

Source: Primary data

Table 2 reveals the over-all satisfaction of the sample respondents and it is found that majority of the talcum powder using consumers are having high level of satisfaction. 
Table 3 : Relationship between the Socio-Economic Factors and Level of Satisfaction

\begin{tabular}{|l|c|c|c|c|}
\hline $\begin{array}{l}\text { Socio-economic } \\
\text { factors }\end{array}$ & $\begin{array}{c}\text { Degrees of } \\
\text { freedom } \\
\text { value }\end{array}$ & $\begin{array}{c}\text { Chi-square } \\
\text { Calculated } \\
\text { value }\end{array}$ & $\begin{array}{c}\text { Chi-square } \\
\text { Table }\end{array}$ & S/NS \\
\hline Age & 3 & 1.1167 & 7.815 & NS \\
Gender & 1 & 0.1268 & 3.841 & NS \\
Occupation & 4 & 10.7537 & 9.488 & S \\
Marifal Status & 4 & 0.7024 & 9.488 & NS \\
Nature of the family & 1 & 6.0618 & 3.841 & S \\
Domicile status & 2 & 0.0366 & 3.841 & NS \\
Monthly Family Income & 2 & 0.3672 & 5.991 & NS \\
\hline
\end{tabular}

Source: Primary Data. S-Significant; NS- Not Significant; Level of Significance-0.05;

Table 3 reveals that the socio-economic factors of education and marital status are significantly associated with the satisfaction level of talcum powder consumers. At the same time, the socio-economic factors such as age, gender, occupation, nature of the family, domicile status and monthly family income are not significantly associated with the satisfaction level of talcum powder consumers.

\section{Recommendations}

1. In this study, it was found that the chemical mixing has been ranked as an important problem of consumers. Hence, it is suggested that the manufacturers of talcum powder may take necessary steps to reduce the chemical mixing content which would help to avoid some skin problems such as skin allergy, pimples etc., occurred to customers.

2. In this study, it was found that there is a significant relationship between the socio-economic factor of education and the satisfaction level. Hence, it is suggested that the manufacturers of various brands of talcum powders may take necessary steps to cater the different needs of consumers having different educational qualifications. 
3. In this study, it was also found that there is a significant relationship between the socio-economic factor of marital status and the satisfaction level. Hence, it is suggested to the manufacturers that they may prepare talcum powders which have the features of satisfying the expectations of both married and unmarried.

\section{Conclusion}

Talcum powder products market is an ever growing one as it becomes a necessary part of human life now-a-days. In this study the problems faced by the consumers of talcum powder and their satisfaction level were studied. On the basis of the findings, some recommendations were made. If those recommendations are carefully considered by the manufacturers of Ponds, Cinthol, Spinz, Gokul Sandal and Mysore Sandal, hopefully they would get remarkable results.

\section{References}

1. "Foods. Drugs and cosmetics", a consumer Guide, Macmillan, 1977, p.73.

2. Philip Kotler "Marketing Management", $7^{\text {th }}$ edition, Prentice Hall of India Pvt. Ltd., 1994, P.181.

3. Vidyadhar Reddy Alien "Advertising effectiveness of Toilet Soaps" Indian Journal of Marketing, volume xxvii, No.9-12, Sep-Dec 1998, pp 24-31.

4. Dr. K. Chidabaram and Dr. S. Ganesan, "Brand Preference of Talcum powder". Indian Journal of Marketing, volume xxxiv, No. 11, Nov. 2004, pp 37-39.

5. Gupta and Raghbirsingh, "Consumer beyond choice behaviour of Television", Indian Journal of Marketing, Vol,xix, No. 6-7, Feb-March, 1989, pp 17-22.

6. Kishorekumar and Rajanath, "Factors influencing consumer decision making process towards biscuits", Indian Journal of Marketing, Vol.-xiii, No.9.10, August 1987, pp 3.9.

7. Bhawna Garg, "Rural Marketing-study of consumer behaviour with reference to Hair oils", Indian Journal of Marketing, Vol.-xxxvii, August 2007, pp 22-24.

8. A.V. Ramana and P. Viswanath, "Consumer behavior and awareness with reference to Edible oil users", Indian Journal of Marketing, Vol.-xxxv, Feb 2005, pp 35-38. 
9. Dr. N. Rajasekar, "Fairness creams- A study on market trends and brand preference", Indian Journal of Marketing, Vol.-xxxii, No-7, July-2002, p-9.

10. Gupta S.P., "Statistical Methods", Sultan Chand \& Sons, New Delhi, 1984.

11. Kothari C.R., "Research Methodology", New Age International (P) Ltd., 2004.

12. www.google.co.in 